\title{
A test of corrections for extraneous signals in gridded surface temperature data*
}

\author{
Ross McKitrick $^{1, * *}$, Patrick J. Michaels ${ }^{2}$ \\ ${ }^{1}$ Department of Economics, University of Guelph, Guelph, Ontario N1G 2W1, Canada \\ ${ }^{2}$ Department of Environmental Sciences, University of Virginia, Clark Hall, 291 McCormick Rd, PO Box 400123, \\ Charlottesville, Virginia 22904-4123, USA
}

\begin{abstract}
Monthly surface temperature records from 1979 to 2000 were obtained from 218 individual stations in 93 countries and a linear trend coefficient determined for each site. This vector of trends was regressed on measures of local climate, as well as indicators of local economic activity (income, gross domestic product [GDP] growth rates, coal use) and data quality. The spatial pattern of trends is shown to be significantly correlated with non-climatic factors, including economic activity and sociopolitical characteristics of the region. The analysis is then repeated on the corresponding Intergovernmental Panel on Climate Change (IPCC) gridded data, and very similar correlations appear, despite previous attempts to remove non-climatic effects. The socioeconomic effects in the data are shown to add up to a net warming bias, although more precise estimation of its magnitude will require further research.
\end{abstract}

KEY WORDS: Global warming · Temperature measurement · Data quality

\section{INTRODUCTION}

Concern is routinely expressed about nonclimatic signals in temperature records. Past studies have typically focused on false warming trends induced by differential characteristics of urban vs. rural landscapes (e.g. Jones et al. 1990, Hansen et al. 2001), inhomogeneities due to discontinuous station maintenance or record-keeping (e.g. Jones \& Moberg 2003) and largescale land-use changes (Pielke et al. 2002, Kalnay \& Cai 2003). Significant urban heat island biases in temperature records have been found in South Africa (Balling \& Hughes 1996), Vienna, Austria (Böhm 1998), China (Jones et al. 1990), Alaska (Magee et al. 1999), Japan (Fujibe 1995), India (Hingane 1996) and others.

Population is typically used as a proxy for extraneous bias, and a common quantification device is to compare rural to urban stations (e.g. Jones et al. 1990, Gallo et al. 1999). This test only suffices if population is a sufficient proxy for nonclimatic temperature trends, but even small villages can experience land-use changes that cause heat island effects (e.g. Torok et al.

\footnotetext{
*Extra information, including the data base and computations, available at: www.uoguelph.ca./ rmckitri/research/ gdptemp.html

**Email: rmckitri@uoguelph.ca
}

2001). Also, an urban-rural comparison is only possible in places where temperature is densely enough sampled that adjacent urban-rural pairs are available, which is not the case everywhere.

Some researchers claim that while nonclimatic factors are present in the raw data, they have been adequately identified and removed. The recent Intergovernmental Panel on Climate Change (IPCC) Working Group I Summary for Policy Makers, referring to a graph of globally averaged temperature data, says only: 'These numbers take into account various adjustments, including urban heat island effects.' (IPCC 2001, p. 1). Beyond that, the possibility of significant nonclimatic effects are not mentioned in the Summary. Within the report itself the discussion of urban heat island effects is brief and leaves the impression that non-climatic signals have been successfully factored out of the raw weather station data. Others have argued that specific nonclimatic effects, such as urban heat islands, only add trivial amounts to what are principally climate trends in published, gridded series (Jones et al. 1990). Hence, the perceived 
validity of temperature data rests on the claim, not that there are no 'fingerprints' of socioeconomic patterns in them, but that they are too small to matter or that they have been identified and removed during the gridding process.

We test this assertion in this paper. We first examine a sample of 218 monthly mean temperature records from the Goddard Institute of Space Studies (GISS) collection, over the 1979 to 2001 interval, and compute the trend at each site. We chose this interval because it is concurrent with the record of tropospheric temperatures estimated by the Microwave Sounding Units (MSUs) on satellite platforms, a record which shows considerably less warming, on a globally averaged basis, than ground-based temperatures (Christy et al. 2003). We show that after controlling for fixed regional variations in climate, including a specific indicator of greenhouse warming, the spatial pattern of trends is significantly correlated with a vector of economic activity and social conditions which are chosen as proxies for a range of potential nonclimatic influences on published temperature data. We then compute trends for the same interval in the gridded land-based data used by the IPCC in grid cells containing the 218 GISS station locations. We show that the same socioeconomic fingerprint remains even after all homogeneity adjustments. These extraneous effects add up to a significant net warming bias at the global level.

The nonclimatic effects are measured while simultaneously controlling for a 'greenhouse' warming factor. Based on theoretical aspects of greenhouse warming quantified by Staley \& Jurica (1970), Michaels et al. (2000) found that the rate of increase in average temperature is directly proportional to the amount of dry air (on a climatological basis) within each IPCC grid cell. In winter, when the mean grid cell dewpoint was

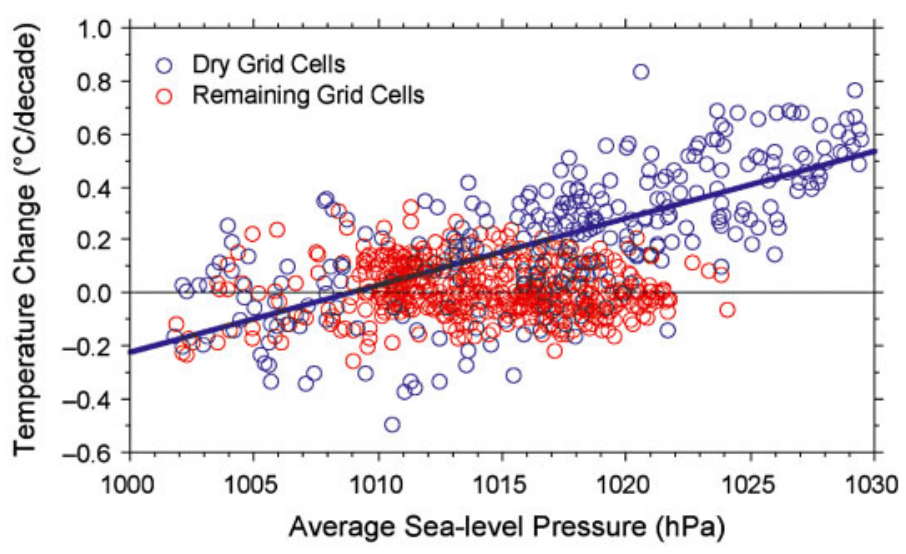

Fig. 1. Relationship between average grid cell pressure and grid cell temperature change for the Northern Hemisphere winter half-year. Dry grid cells: grid cells with a seasonal average dewpoint temperature less than $0^{\circ} \mathrm{C}$. From Michaels et al. (2000) below $0^{\circ} \mathrm{C}$, the rate of warming was directly proportional to the average grid cell surface barometric pressure. When the dewpoint was above $0^{\circ} \mathrm{C}$, the rate of recent warming was statistically insignificant. This result is consistent with physical explanations of warming due to infrared absorption and its rather striking presentation (Fig. 1) allows its inclusion in this study as a specific (though not exhaustive) indicator of greenhouse warming. Our results will show that indeed the amount of dry air predicts the dominant fraction of warming in the cold season, but outside the dry/cold regions the measured temperature change is primarily explained by economic and social variables.

Proposing a causal relationship between national socio-economic conditions (such as income and literacy) and the quality of local meteorological data requires justification. A possible mechanism by which economic activity, and attendant land-use changes, affects measures of sensible heat is an induced change in the local Bowen ratio (e.g. Friedrich et al. 2000, Pielke et al. 2003). Other mechanisms might include changes to local atmospheric chemistry from air pollution. Data quality can also be affected by economic conditions. Climate stations are costly to construct, maintain and operate. In the US, this has at times required a full time national staff of over 450 trained personnel (Linacre 1992, p. 31). Meteorological equipment must be kept in good working order, with recommended inspections once a week or immediately after a severe weather disturbance, as well as full maintenance and calibration twice a year, with immediate repair or replacement of defective instruments (Environment Canada, Guidelines for Cooperative Climatological Autostations Version 2.0). In much of the world, the resources needed to attain these standards would be considered a 'luxury.' Since public resources are required, the quality of station data is not independent of general economic conditions.

Measures to protect data quality can be resource-intensive. For instance, redundant weather stations can be set up in remote and rural locations to increase the spatial sample and control for urban heat bias, but then staffing costs rise since stations are still required at urban airports. The burden of maintaining the network of weather stations has evidently proven onerous: two-thirds of the world's stations have been closed since the 1970s, taking the number of active sites in the Global Historical Climatology Network from about 6000 down to 2000 over the past two and a half decades (Peterson \& Vose 1997).

In countries with relatively low educational attainment, skilled labour is scarce and hence its 
real cost is higher than in countries with advanced educational systems. This constrains the ability of a national meteorological service to hire and retain technical staff for data collection and managing meteorological equipment. While there is no a priori reason to assume this will bias temperature trends up (or down), it could lead to a warming bias if non-urban stations become under-used, if Stevenson Screens are allowed to discolor, or if cold weather events interfere with data collection more often than warm events. An observed spatial pattern of published surface trends and the spatial pattern of educational attainment does not imply anything about the competence of individuals who look after the meteorological instruments, instead the concern is that economic conditions impose a constraint on the overall quality control process.

The next section introduces the data set and the empirical model. Section 3 presents results. Section 4 discusses model specification tests and Section 5 tests out-of-sample prediction ability. Section 6 uses the estimation results to remove nonclimatic trends from the data. Section 7 presents a summary and conclusions.

\section{DATA AND EMPIRICAL MODEL}

The variables used in the study are described in Table 1 and summary statistics are in Table 2. The empirical model is a regression of the surfacemeasured temperature trend on 3 groups of variables. The first group (PRESS $\left.{ }_{i}, W A T E R_{i}, C O S A B L A T_{i}\right)$ represents the climatic factors (including those related to potential greenhouse mechanisms) that logically explain variations in the temperature trend, including the regional mean air pressure in the dry regions, coastal proximity, and the cosine of absolute latitude. The second group $\left(P O P_{i}\right.$ to $\left.G D P G R O W_{i}\right)$ represents economic factors and consists of population, scale of local economic activity, coal use and economic growth rates. The third group (SOVIET to $_{i}$ LIT79 $_{i}$ ) represents data management factors including the local literacy rate and the number of months of missing data in the local temperature record. No a priori assumptions are made as to whether extraneous influences would lead to a net warming or cooling effect; instead the data are allowed to determine the signs and sizes of all coefficients. Note that some variables can simultaneously

Table 1. Variable names and descriptions. OLS: ordinary least squares; GISS: Goddard Institute of Space Studies; GHCC: Global Hydrology and Climate Center; GDP: gross domestic product

\begin{tabular}{|c|c|c|}
\hline $\begin{array}{l}\text { Variable name } \\
\text { (referring to location } i \text { ) }\end{array}$ & Code & Description \\
\hline Station trend & $S T R E N D_{i}$ & $\begin{array}{l}\text { Slope coefficient from OLS regression of GISS monthly average temperature } \\
\text { level on time trend spanning 1979:1 = } 1 \text { to } 2000: 12=264\end{array}$ \\
\hline Grid cell trend & $G T R E N D_{i}$ & $\begin{array}{l}\text { Slope coefficient from OLS regression of } 5 \times 5 \text { grid cell mean temperature level } \\
\text { at location } i \text { on time trend spanning 1979:1 }=1 \text { to } 2000: 12=264\end{array}$ \\
\hline Tropospheric trend & $M T R E N D_{i}$ & $\begin{array}{l}\text { Slope coefficient from OLS regression of GHCC monthly average temperature } \\
\text { level on time trend spanning 1979:1 = } 1 \text { to } 2000: 12=264\end{array}$ \\
\hline Air pressure & $\mathrm{PRESS}_{i}$ & Local mean surface air pressure in bars \\
\hline Proximity to water & $W A T E R_{i}$ & Location is adjacent to ocean or major body of water \\
\hline Absolute latitude & COSABLAT & Cosine of absolute value of latitude in degrees \\
\hline Population & $P O P_{i}$ & Population of city, town or rural area where thermometer is located \\
\hline Scale & $S C A L E 79_{i}$ & $\begin{array}{l}\text { Scale of local economic activity in } 1979 \text { (per capita income times local } \\
\text { population } P O P_{i} \text { ) }\end{array}$ \\
\hline Coal use in 1980 & $C O A L 80_{i}$ & National coal use in 1980 in million short tons \\
\hline $\begin{array}{l}\text { Growth in coal } \\
\text { consumption }\end{array}$ & COALGROW & $\begin{array}{l}\text { Average (compound) annual percent growth in national coal use from } 1980 \text { to } \\
1998 .\end{array}$ \\
\hline Initial per capita income & INC $79_{i}$ & $\begin{array}{l}1979 \text { real GDP per capita using } 1985 \text { international prices, in US\$1000 per } \\
\text { annum }\end{array}$ \\
\hline GDP growth rate & GDPGROW & $\begin{array}{l}\text { Average (compound) annual growth rate in national real GDP (local currency) } \\
\text { between } 1979 \text { and } 2000\end{array}$ \\
\hline Soviet membership & SOVIET $_{i}$ & $\begin{array}{l}\text { A dummy variable that takes the value of } 1 \text { if the station was located in a } \\
\text { member of the former Soviet Union and } 0 \text { otherwise }\end{array}$ \\
\hline Number of missing values & SURFMISS $_{i}$ & $\begin{array}{l}\text { The number of months between } 1979: 1 \text { and } 2000: 12 \text { in which temperature data } \\
\text { were missing from the temperature record }\end{array}$ \\
\hline Literacy & $\operatorname{LIT}_{7} 9_{i}$ & $\begin{array}{l}\text { Average national literacy rate, males and females, in } 1979 \text { or the earliest } \\
\text { available year thereafter }\end{array}$ \\
\hline
\end{tabular}


Table 2. Summary statistics. Number of observations $=218$ except for GTREND $D_{i}$ where number is 205. Lat $_{i}$ : latitude $\left({ }^{\circ}\right)$; see Table 1 for other variable names and descriptions

\begin{tabular}{|c|c|c|c|c|}
\hline Name & Mean & SD & Min. & Max. \\
\hline$S_{T R E N D_{i}}$ & 0.32 & 0.46 & -1.55 & 1.43 \\
\hline GTREND & 0.27 & 0.24 & -0.47 & 0.91 \\
\hline MTREND & 0.18 & 0.22 & -0.21 & 0.76 \\
\hline$P R E S S_{i}$ & 1014.9 & 4.99 & 987 & 1029 \\
\hline$W A T E R_{i}$ & 0.47 & 0.50 & 0 & 1 \\
\hline$L A T_{i}$ & 25.2 & 32.3 & -75.5 & 80.0 \\
\hline$P O P_{i}^{\text {a }}$ & 5.9 & 15.06 & 0 & 116.7 \\
\hline$S C A L E 79_{i}^{\mathrm{b}}$ & 5.28 & 15.53 & 0 & 113.9 \\
\hline COAL $80_{i}$ & 0.131 & 0.232 & 0.0 & 0.701 \\
\hline COALGROW & 1.0 & 5.41 & -16.8 & 18.77 \\
\hline$I N C 79_{i}$ & 6.44 & 4.98 & 0.32 & 26.71 \\
\hline GDPGROW $_{i}$ & 0.52 & 1.71 & -8.77 & 5.37 \\
\hline SOVIET $_{i}$ & 0.20 & 0.40 & 0 & 1 \\
\hline SURFMISS $_{i}$ & 23.5 & 28.24 & 0 & 138 \\
\hline$L I T 79_{i}$ & 79.8 & 26.98 & 8.0 & 99.0 \\
\hline \multicolumn{5}{|c|}{$\begin{array}{l}\text { a Population is in } 100000 \text { 's } \\
\text { b } \\
\text { bcale is in billions \$US }\end{array}$} \\
\hline
\end{tabular}

measure both economic and climatic effects: coal consumption for instance is correlated with air emissions but is also a descriptor of a nation's economic situation.

Note that the dependent variable at each location $i$ is not a temperature level but a trend over the interval 1979 to 2000 . The regression model developed here does not require information on the variance of the trend, so problems related to inference in the present of serial correlation or stochastic trends are not of concern. Stationspecific surface temperature trends over the period 1979 to 2000 are computed using monthly data from 218 sites in 93 countries (Table 3 \& Fig. 2). These data were obtained from GISS (2002) using the series combined at a single location, after homogeneity adjustment. The sample represents about $10 \%$ of active climate stations in the GISS collection. Further adjustments to data from the US and southern Canada were made by GISS after this sample was collected. The adjustments are explained in Hansen et al. (2001) and are generally small. The data in this study are the ones on which the assertions in the IPCC (2001) report were based.

Stations were sampled from all 7 continents, with the intent to draw from as many different countries as possible. Additional coverage of Canada, the US and Russia was done to improve the spatial spread. Stations were selected for this sample only if they were in continuous operation from 1979 through 2000, and the data were available in the GISS on-line collection. The selection of GISS stations was made prior to the compilation of the socioeconomic covariates, and no additions or deletions to the list were made once the data analysis was underway. A follow-up study will extend the analysis herein to the entire land-based IPCC grid cell collection.

The monthly GISS Station temperatures at each location $i$ are denoted $S_{i}(t)$. For each location $i=$ $1, \ldots, 218$, a separate ordinary least squares (OLS) regression of $S_{i}(t)$ on the time trend $t$ was run:

$$
S_{i}(t)=\mathrm{a}_{i}+S T R E N D_{i} \times t+\mathrm{e}_{i t}
$$

Here $\mathrm{a}_{i}$ is a constant term ( 1 for each station) and $t$ runs from 1 to 264, covering the interval from 1979:1 to 2000:12. The least-squares slope coefficients from Eq. (1) fill the vector $S T R E N D_{i}$. We chose this interval because it is the period of apparently rapid warming that has generated concern about anthropogenic cli-

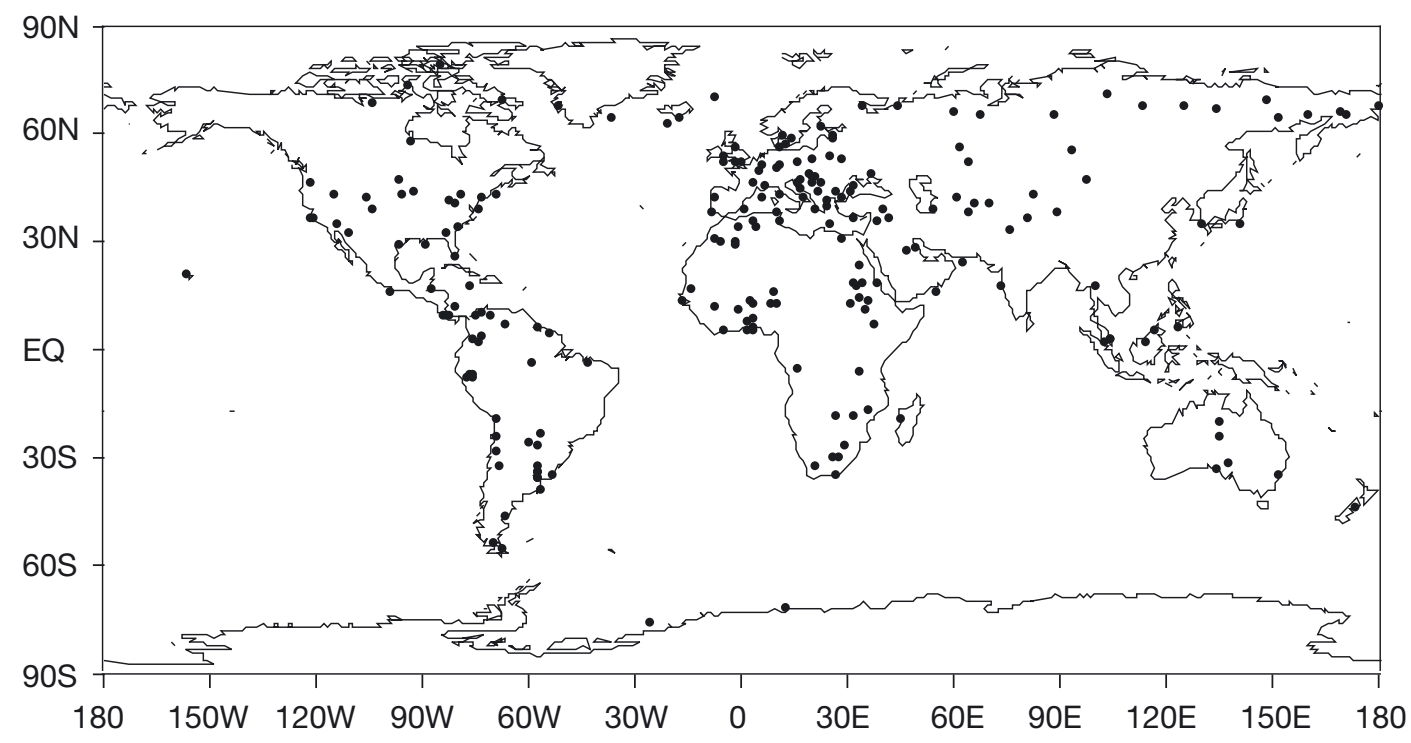

Fig. 2. Locations of Goddard Institute of Space Studies (GISS) station data 
mate change, and because it is concurrent with the record of tropospheric temperatures estimated by the MSUs on satellite platforms, a record which shows considerably less warming, on a globally averaged basis, than ground-based temperatures (Christy et al.
2003). These data are used for a specification test later in the paper.

A second vector of trends were taken from the IPCC gridded temperature departures in $5^{\circ} \times 5^{\circ}$ grid cells corresponding to the surface station trend locations.

Table 3. Station sample locations

\begin{tabular}{|c|c|c|c|}
\hline Toronto, Canada & Mar Del Plata, Argentina & Sofia, Bulgaria & Sydney, Australia \\
\hline Clyde, Canada & Salto, Argentina & Varna, Bulgaria & Christchurch, New Zealand \\
\hline Eureka, Canada & Ezeiza, Argentina & Sulina, Romania & Kuantan, Indonesia \\
\hline Resolute, Canada & Gualeguaychu, Argentina & Bucuresti, Romania & Iliastai, Mongolia \\
\hline Cambridge Bay, Canada & Buenos Aires, Argentina & Sliac, Slovakia & Tokyo, Japan \\
\hline Churchill, Canada & Comodoro Riva, Argentina & Poprad, Slovakia & Pohang, Korea \\
\hline San Francisco, CA, USA & Punta Arenas, Argentina & Odesa, Ukraine & Miliana, Algeria \\
\hline Honolulu, HI, USA & Ushuaia, Argentina & Erzincan, Turkey & Djelfa, Algeria \\
\hline Austin, TX, USA & Las Lomitas, Argentina & Isparta, Turkey & El Golea, Algeria \\
\hline Santa Cruz, CA, USA & Puerto Casado, Paraguay & Lisboa, Portugal & Beni Abbes, Algeria \\
\hline Phoenix, AZ, USA & Mercedes, Uruguay & Krasnojarsk, Russia & Beni-Saf, Algeria \\
\hline Fort Meyers, FL, USA & San Juan, Puerto Rico & Olenek, Siberia & Ouarzazate, Morocco \\
\hline New Orleans,LA, USA & Egedesminde, Greenland & Hatanga, Russia & Marrakech, Morocco \\
\hline Atlanta, GA, USA & Akureyri, Iceland & Turuhansk, Russia & Tunis, Tunusia \\
\hline Charlotte, NC, USA & Reykjavik, Iceland & Dzardzan, Russia & Aswan, Egypt \\
\hline Philadelphia, PA, USA & Belfast, Ireland & Ilirnej, Russia & Mersa Matruh, Egypt \\
\hline Albany, NY, USA & Dublin, Ireland & Salehard, Russia & Port Sudan, Sudan \\
\hline Portland, OR, USA & Waddington, England & Murmansk, Russia & Damazine, Sudan \\
\hline Cleveland, OH, USA & Manchester, England & Kanin Nos, Russia & Gedaref, Sudan \\
\hline Detroit, MI, USA & Aberdeen, Scotland & Cokurdah, Russia & Abu Hamed, Sudan \\
\hline Minneapolis, MN, USA & Ålborg, Denmark & Verhojansk, Russia & El Obeid, Sudan \\
\hline Grand Forks, ND, USA & Angmagssalik, Greenland & Mys Smidta, Russia & Karima, Sudan \\
\hline Sioux Falls, SD, USA & Jan Mayen, Greenland & Zyrjanka, Russia & Dongola, Sudan \\
\hline Casper, WY, USA & Oslo, Norway & Ust'-Oloj, Russia & Khartoum, Sudan \\
\hline Boise, ID, USA & Karlstad, Sweden & Mys Uelen, Russia & Jimma, Ethiopia \\
\hline Las Vegas, NV, USA & Göteborg, Sweden & Hoseda-Hard, Russia & Tabora, Tanzania \\
\hline Seattle, WA, USA & Vaasa, Finland & Sverdlovsk, Russia & Brazzaville, Congo \\
\hline Denver, CO, USA & Helsinki, Finland & Kustanai, Kazakhstan & Chileka, Malawi \\
\hline Acapulco, Mexico & Tallin, Estonia & Cardzou, Turkmenistan & Maintirano, Madagascar \\
\hline Belize/Philli, Belize & Kaunas, Lithuania & Krasnovodsk, Turkmenistan & Harare, Zimbabwe \\
\hline Puerto Limon, Honduras & Szczezin, Poland & Tashkent, Uzbekistan & Livingstone, Botswana \\
\hline Puntarenas, El Salvador & Elblag, Poland & Cimbaj, Uzbekistan & Bloemfontein, South Africa \\
\hline Montego Bay, Jamaica & Minsk, Belarus & Tamdy, Uzbekistan & Kimberley, South Africa \\
\hline Santa Marta, Colombia & Hannover, Germany & Kuwait City, Kuwait & Port Elizabeth, South Africa \\
\hline Cartagena, Colombia & Kassel, Germany & Al Qaysumah, Saudi Arabia & Calvinia, South Africa \\
\hline Neiva, Colombia & De Bilt, Netherlands & Kamishli, Syria & Jan Smuts, South Africa \\
\hline Cali, Colombia & Marseille, France & Aleppo, Syria & Tillabery, Niger \\
\hline Bogota, Columbia & Bourges, France & Salalah, Oman & Maradi, Niger \\
\hline Maracaibo, Venezuela & Graz-Thalerho, Austria & Jiwani, Pakistan & Agadez, Niger \\
\hline San Fernando, Venezuela & St. Poelten, Austria & Srinagar, India & Zinder, Niger \\
\hline Juan Santamar, Costa Rica & Ostrava, Czech Republic & Souda, India & Niamey, Niger \\
\hline San Andres, Guatemala & Geneve, Switzerland & Bombay, India & Bohicon, Benin \\
\hline Georgetown, Guyana & Cagliari, Italy & Ruoqiang, China & Parakou, Benin \\
\hline Zanderij, Suriname & Pisa, Italy & Hotan, China & Cotonou, Benin \\
\hline Chachapoyas, Peru & La Coruña, Spain & Yining, China & Sokode, Togo \\
\hline Juanjui, Peru & Valencia, Spain & Chiang Mai, Thailand & Lome, Togo \\
\hline Cajamarca, Peru & Uccle, Belgium & Kuala Lumpur, Malaysia & Gagnoa, Cote D'Ivoire \\
\hline Tarapoto, Peru & Split/Marjan, Croatia & Bintulu, Malaysia & Bamako, Mali \\
\hline Sao Luiz, Brazil & Zagreb, Croatia & Kota Kinabalu, Malaysia & Ouagadougou, Burkina Faso \\
\hline Rocha, Brazil & Debrecen, Hungary & Kuantan, Malaysiaw & Dakar, Senegal \\
\hline Manaus, Brazil & Kharkiv, Hungary & Zamboanga, Philippines & Boutilimit, Mauritania \\
\hline Copiapo, Chile & Budapest, Hungary & Alice Springs, Australia & Novolazaresk, Antarctica \\
\hline Arica, Chile & Belqrade, Yugoslavia & Woomera Aerod, Australia & Halley, Antarctica \\
\hline Antofagasta, Chile & Thessaloniki, Greece & Ceduna, Australia & \\
\hline Formosa, Arqentina & Kerkyra, Greece & Tennant Creek, Australia & \\
\hline
\end{tabular}


Monthly data for the period 1979:1 to 2000:12 were obtained from the Climate Research Unit at the University of East Anglia (www.cru.uea.ac.uk/cru/data/ temperature). These data form the basis for the temperature histories published by the United Nations' IPCC. Temperature observations for time $t$ at location $i$ are denoted $G_{i}(t)$. The trend was estimated using 218 OLS regressions of the form

$$
G_{i}(t)=\mu_{i}+G T R E N D_{i} \times t+v_{i t}
$$

yielding the gridded data trend coefficients $G T R E N D_{i}$ for the 218 sample locations.

Table 2 shows that the mean surface station trend is about $0.32^{\circ} \mathrm{C} /$ decade. This is higher than the globally averaged surface trend during this period $\left(0.18^{\circ} \mathrm{C} /\right.$ decade) because the sample here is more heavily weighted towards the Northern Hemisphere (the average latitude is about $25^{\circ} \mathrm{N}$ ). The mean grid cell trend is $0.27^{\circ} \mathrm{C} /$ decade. Although there was at least 1 active GISS station in each of the 218 grid cells, 13 corresponding cells in the IPCC collection did not report data and had to be excluded from the analysis. The average trend in the 13 GISS stations corresponding to the empty IPCC grid cells was $-0.03^{\circ} \mathrm{C} /$ decade, indicating that some of the magnitude of warming in the IPCC calculations is due to the loss of grid cells with below-average (and in particular negative) trends.

For each station, locationally fixed geographical factors include mean air pressure $\left(P R E S S_{i}\right)$, cosine of absolute latitude (COSABLAT $\left.T_{i}\right)$, and a dummy variable $\left(W A T E R_{i}\right)$ representing proximity to an ocean coast or a large body of water (e.g. the Great Lakes). Air pressure is included to pick up a 'greenhouse'-warming mechanism, as noted above. Enhanced warming trends in dry, high pressure zones have been observed, particularly in the Siberian anticyclone (Michaels et al. 2000). The source of the pressure data is the climatology of Jenne (1974).

The economy and development status of a country can be measured many ways, but there are some conventional variables that are typically used in crosscountry comparisons (e.g. Heston \& Summers 1991). These include population, real national Gross Domestic Product (GDP), GDP growth rates, average income, energy usage, real consumption, export volumes, inflation, interest and exchange rates and the relative size of the public sector. Of these, the first 5 are used herein, as these are the most likely to have some relationship to measurement of the surface temperature field. The others might indirectly have an effect, but if so it would likely be mediated through GDP or income.

Economic variables at each location include population $\left(P O P_{i}\right), 1979$ real per capita income $\left(I N C 79_{i}\right)$, and average growth in annual real national GDP from 1979 to $2000\left(G D P G R O W_{i}\right)$. In each case except population the data refer to the country in which the weather station is located. The population measure is the GISS record of the city population in which the station is located, and was set to zero for places designated 'rural area.' For income and other measures it would have been preferable to use data for the specific region in which the weather station sits, but such detail is not available.

National income can interact with temperature data in several ways. Higher levels of income imply more resources are available for quality control, but may also indicate more intensive land-use changes or local air pollution loads. 1979 income was measured as real GDP per capita in 1985 constant (thousand) dollars at international prices (code RGDPC), taken from the Penn World Tables (Heston \& Summers 1991). In the case of the former Soviet Union, USSR figures were used for Russia and the smaller republics, while for some former members separate income figures were available from the World Bank Global Development Network $\left(\right.$ WBGDN) ${ }^{1}$ and the CIA World Factbook $(\mathrm{CIAWF})^{2}$. Yugoslavia income was used for Bosnia and Croatia. Greenland stations were considered part of Denmark for economic measures, and income for Antarctica stations were based on the administering country.

Data from WBGDN were used to calculate the average annual growth rate in national real GDP between 1979 and 2000 in (inflation-adjusted) local currency. For those former Sovietdominated economies in which the country broke apart (e.g. Czechoslovakia) the growth rate for the separate countries was estimated by taking a common pre-breakup income level and comparing it to 2000 income in the post-breakup region.

A variable called $S C A L E 79_{i}$ was created as the product of 1979 local per capita income and local population. Since it shows average real income times local population, it provides a measure of the total scale of measured economic activity in the station's vicinity. Variations in the scale measure can potentially capture some local changes in land-use and/or air pollution that are not reflected in population or national economic data.

Data on coal consumption for each country from 1980 to 1998 were obtained from the US Energy Information Administration (USEIA) ${ }^{3}$. The variable $C O A L 80_{i}$ shows the 1980 total national coal consumption in million short tons. The variable COALGROW shows the average (compound) annual increase in total coal consumption from 1980 to 1998. Coal use adds sul-

\footnotetext{
${ }^{1}$ WBGDN Database; www.worldbank.org/research/growth/ GDNdata.htm

${ }^{2}$ CIAWF; www.odci.gov/cia/publications/factbook/index.html ${ }^{3}$ USEIA; www.eia.doe.gov/emeu/iea/
} 


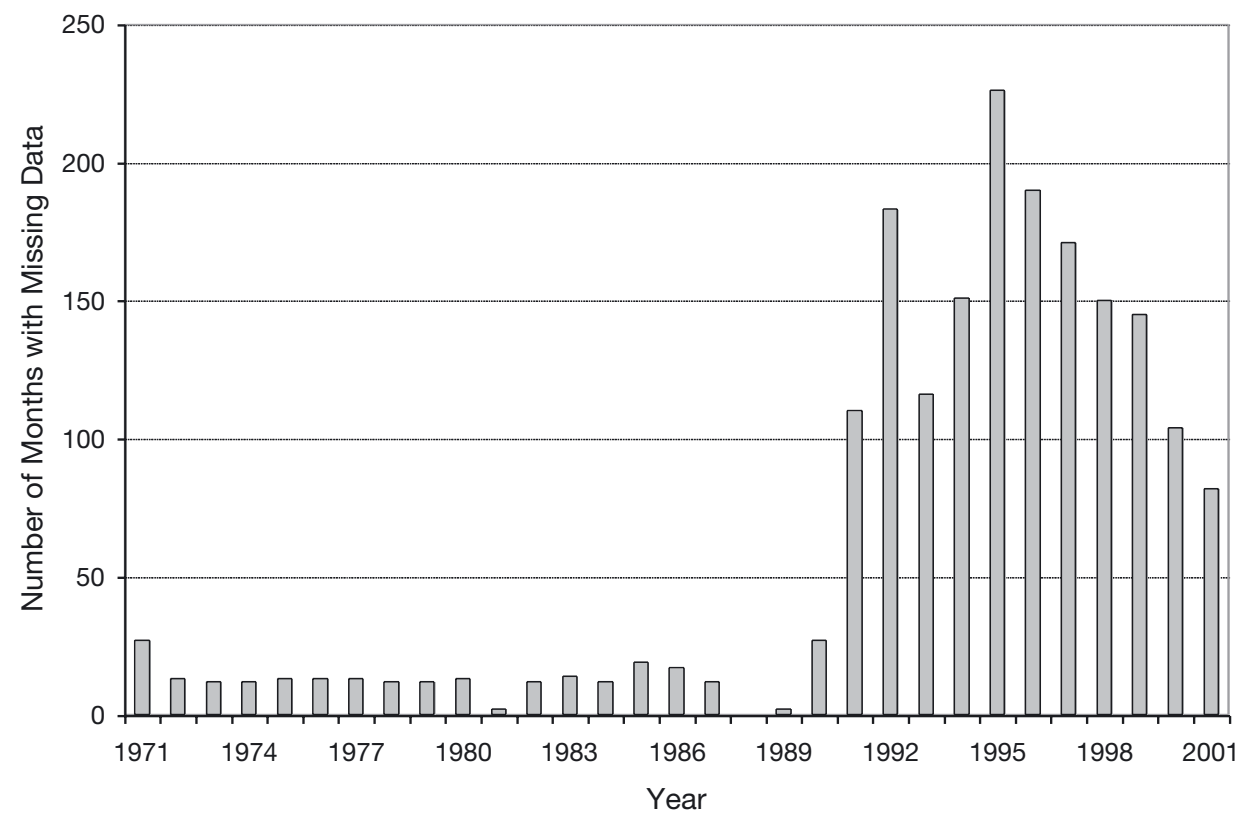

Fig. 3. Number of months each year in which temperature data was missing in one of the 110 climate stations in the GISS collection that were located in the former Soviet Union and that operated continuously over the period 1979 to 2001

fate particulates to local atmospheres, with a cooling effect that has been documented over the eastern US, Europe and China (Charlson et al. 1992). By facilitating electrification, coal may reduce some fuel use in cities and thereby reduce local waste heat loads, although these are generally assumed to be very small compared to the effect of urbanization on the local radiation balance. It also provides a measure of the nature and intensity of energy use in an economy. As such, coal is both an economic variable and a climatic variable and one should be cautious in interpreting its role in the model below.

Measures of social influences on data quality include literacy, the number of missing observations at each station, and whether the data originated in the Soviet Union. LIT 79 $9_{i}$ is the 1979 average literacy rate for the country, taken from UNESCO ${ }^{4}$ for 1979 , or the closest year thereafter if 1979 was missing. In all OECD countries it is conventional to record the literacy rate as $99 \%$, so only in non-OECD countries is there variation in this measure. As discussed above this variable is included as a proxy for the general availability of skilled postsecondary-educated workers.

SURFMISS $S_{i}$ is the number of months between 1979:1 and 2000:12 in which the observation is missing at

\footnotetext{
${ }^{4} \mathrm{UNESCO}$ world education indicators http://unescostat. unesco.org/en/stats/stats0.htm
}

either surface station $i$ or the corresponding IPCC grid cell, depending on which is the dependent variable.

Data from the former Soviet Union was identified as a potential source of quality problems because of the extraordinary political and economic disruption that occurred after 1989. The collapse of the Soviet Union had large effects on public budgets, staffing and resources for scientific work. It is reasonable to suppose that this introduced a discontinuity in the nature of the temperature sample from the region covered by the former Soviet Union. For example, Fig. 3 shows the number of months per year in which observations were missing in at least 1 of the 110 Russian climate stations that operated continuously over the period 1979 to 2001 and that are available in the GISS on-line collection. Note that this does not reflect the closure of stations, but the reporting of data from stations that remained open. The change in the completeness of the sample after 1989 is quite apparent. To capture quality-control effects unique to this region a dummy variable, SOVIET $T_{i}$ is created which takes a value of 1 if the country belonged to the Soviet Bloc and 0 otherwise. Note that this portion of the analysis is potentially confounded with specification of the greenhouse signal in dry air via the pressure data, because large areas of Russia are affected by the Siberian anticyclone. The pressure data and the Soviet dummy are included in the regression equation simultaneously in order to avoid imposing any prior assumption on which effect is predominant. 
The basic regression equation is

$$
\begin{aligned}
\text { STREN }_{i}=\alpha+\gamma_{1} \text { PRESS }_{i}+\gamma_{2} \text { WATER }_{i}+\gamma_{3} \text { COSABLAT } & +\beta_{1} \text { OOP }_{i}+\beta_{2} \text { SCALE79 }_{i}+\beta_{3} \text { COAL }_{i} \\
& +\beta_{4} \text { COALGROW }_{i}+\beta_{5} \text { INC7 }_{i}+\beta_{6} \text { GDPGROW } \\
& +\theta_{1} \text { SOVIET }_{i}+\theta_{2} \text { SURFMISS }_{i}+\theta_{3} \text { LIT79 }_{i}+\varepsilon_{i}
\end{aligned}
$$

where $\alpha$ is a constant and $\varepsilon$ is a zero-mean disturbance term. All estimations are done using the econometrics program SHAZAM (White 1993) and use a heteroskedasticity-consistent covariance matrix estimator (White 1980).

The $\gamma_{j}$ 's are the coefficients that measure the climatic effects. The $\beta_{j}$ 's measure economic effects and the $\theta_{j}$ 's measure political and social factors that may impinge upon quality control. Eq. (2) is also re-run with GTREND as the dependent variable to test if the same factors affect the gridded data trends. Some other variations to Eq. (2) will be discussed in subsequent sections.

Table 4. Parameter estimates for surface data 'fingerprint' model. $t$-statistic in parentheses, based on White's (1980) heteroskedasticity-consistent covariance matrix estimator. Coefficient estimates in bold: significant at $95 \%$; ${ }^{*}$ : significant at $90 \%$. Dependent variable is in ${ }^{\circ} \mathrm{C} /$ decade. $\mathrm{R}^{2}$-Geog: adjusted $\mathrm{R}^{2}$ from a regression of the surface trends on the geographic variables $\left(P R E S S_{i}\right.$ through COSABLAT $)$ only. $P($ Econ $=0)$ : $\mathrm{p}$ value of an $F$-test on the hypothesis that the economic influence variables $\left(P O P_{i}\right.$ through $\left.G D P G R O W_{i}\right)$ are jointly zero. $P(\operatorname{Sov}=0)$ : $\mathrm{p}$-value of a $t$-test on the hypothesis that the Soviet dummy is zero. $P(\mathrm{Soc}=0)$ : $\mathrm{p}$-value of an $F$-test on the hypoth-

\begin{tabular}{|c|c|c|c|c|}
\hline \multirow{3}{*}{$\begin{array}{l}\text { Variable } \\
\text { Dependent variable } \\
\text { CONSTANT }\end{array}$} & \multirow{2}{*}{\multicolumn{2}{|c|}{$\begin{array}{c}\text { Station data } \\
\text { Global sample } \\
\text { STREND }\end{array}$}} & \multirow{2}{*}{\multicolumn{2}{|c|}{$\begin{array}{c}\text { Gridded data } \\
\text { Global sample } \\
\text { GTREND }\end{array}$}} \\
\hline & & & & \\
\hline & -12.727 & $(1.16)$ & -9.124 & (2.13) \\
\hline$P R E S S_{i}$ & 0.013 & $(1.18)$ & 0.009 & (2.18) \\
\hline WATER $R_{i}$ & $0.103^{*}$ & (1.91) & 0.012 & $(0.39)$ \\
\hline$C O S A B L A T_{i}$ & -0.008 & $(0.20)$ & -0.048 & (2.46) \\
\hline$P O P_{i}$ & 0.002 & $(0.60)$ & -0.002 & $(1.26)$ \\
\hline$S C A L E 79_{i}$ & -0.002 & $(0.51)$ & -0.000 & $(0.02)$ \\
\hline COAL80 & -0.450 & $(2.72)$ & -0.323 & (3.40) \\
\hline COALGROW & $-0.007^{*}$ & $(1.68)$ & -0.002 & $(0.85)$ \\
\hline$I N C 79_{i}$ & 0.046 & (4.46) & 0.030 & (5.22) \\
\hline GDPGROW $_{i}$ & 0.091 & (4.55) & 0.039 & (3.68) \\
\hline SOVIET $_{i}$ & 0.592 & (5.46) & 0.288 & (4.73) \\
\hline SURFMISS $_{i}$ & -0.000 & $(0.09)$ & -0.001 & $(0.16)$ \\
\hline$L I T 79_{i}$ & -0.005 & (2.99) & -0.002 & (2.81) \\
\hline $\mathrm{R}^{2}$ & 0.25 & & 0.29 & \\
\hline Adj-R $R^{2}$ & 0.20 & & 0.25 & \\
\hline $\mathrm{R}^{2}$-Geog & 0.04 & & 0.06 & \\
\hline$P($ Econ $=0)$ & 0.00 & & 0.00 & \\
\hline$P($ Sov $=0)$ & 0.00 & & 0.00 & \\
\hline$P(\mathrm{Soc}=0)$ & 0.01 & & 0.02 & \\
\hline df & 205 & & 192 & \\
\hline
\end{tabular}
esis that social factors potentially affecting data quality $\left(S U R F M I S S_{i}\right.$ and $L I T 79_{i}$ ) are jointly zero. See Table 1 for other variable names and descriptions

\section{EMPIRICAL RESULTS}

\subsection{Global sample}

The results for the global sample are in Table 4 . The first column shows the parameter estimates from a regression with dependent variable $S T R E N D_{i}$, the station-based vector of trends, and the second column is with dependent variable GTREND $D_{i}$, the gridded and 'corrected' IPCC data. Throughout the tables bold denotes significance at $95 \%$ while ${ }^{*}$ denotes significance at $90 \%$.

Regarding fixed climate effects, air pressure has a positive effect on the observed trend, with the coefficient similar in the 2 samples (about $+0.01^{\circ} \mathrm{C} /$ decade $\mathrm{mbar}^{-1}$ ) but is significant only in the gridded version. The cosine of absolute latitude has a negative and significant impact on the gridded trends, consistent with high-latitude amplification of warming. The negative sign is persistent across most specifications and always occurs where the coefficient is significant. Proximity to water has a positive and marginally significant effect in the station data. The measure labeled $\mathrm{R}^{2}$-Geog is the adjusted $\mathrm{R}^{2}$ from a regression on the geographical variables only, which explain only 0.04 to $0.06 \%$ of the trend patterns.

The parameters on population and local economic scale are numerically small and insignificant, suggesting that attempts to detect extraneous signals in surface temperature data based simply on correlations with local population or urban-rural comparisons are likely to miss important factors.

Coal use generates a significant local cooling effect: an additional 1 billion short tons of national coal consumption is associated with a $-0.45^{\circ} \mathrm{C} /$ decade change in the local station temperature. This effect carries over to the gridded data where it is slightly smaller $\left(-0.32^{\circ} \mathrm{C} /\right.$ decade $)$ but still highly significant. Crosssectional variation in coal consumption tends to be fairly stable over the 2 decades covered by this study, but for regions where coal use did change, growth in coal consumption appears to be a weakly significant predictor of cooling in the station data. However, this effect does not appear in the gridded sample. Examination of subsamples will show that the coal effect is concentrated in high-income settings, primarily in the warm season. As noted earlier, the meaning of these effects is ambiguous since coal is both an economic descriptor and a local climate variable.

Other economic factors matter significantly and carry over from the station data to the IPCC data. Where the effect is significant in the station data sample, it is smaller but still significant in the gridded data. An increase of US\$1000 in 1979 average real income is associated with an increased local 
warming trend of about $0.05^{\circ} \mathrm{C} /$ decade in the station data and $0.03^{\circ} \mathrm{C} /$ decade in the gridded data. The GDP growth rate is also significant: every $1 \%$ of additional long-term annual real economic growth adds, on average, $0.09^{\circ} \mathrm{C} /$ decade to the measured station trend and $0.04^{\circ} \mathrm{C} /$ decade to the corresponding gridded trend. The economic factors are jointly significant (see Table 4, row $P($ Econ $=0)$ ) at over $99 \%$ for each sample.

Social and political factors also leave a fingerprint on the data. There is a very large fixed Soviet effect of $+0.59^{\circ} \mathrm{C} /$ decade in the station sample, which becomes a smaller but still significant $+0.29^{\circ} \mathrm{C} /$ decade in the gridded sample. Recall that this is after controlling for the pressure-based 'greenhouse' warming in the Siberian region, income levels and growth rates, etc. A test of the hypothesis that this coefficient is zero rejects at over $99 \%$ significance $(P(\operatorname{Sov}=0))$ in each sample. The meaning of this coefficient is not straightforward. It may reflect problems due to disruptions in data quality control, or it may reflect inadequate controls within the model for high-latitude climatic change based on dry anticyclones, since maximum warming, Soviet status, and maximum barometric pressure (due to the Siberian anticyclone), are not geographically independent. However,it clearly points to the need to understand the nature of the temperature data from the Soviet Union, because of their considerable influence on the global averages that are used to quantify climate change.

The results also indicate that a $10 \%$ reduction in the local literacy rate is associated with a $0.05^{\circ} \mathrm{C} /$ decade increase in the reported station warming rate, which reduces to $+0.02^{\circ} \mathrm{C} /$ decade effect in the gridded sample but remains significant. The data in this sample (and by implication in any global sample) comes from countries whose literacy rates range from 99 to $8 \%$, with an average just below $80 \%$. The number of missing observations in the local record appears not to play a role on the temperature trend over the whole sample, though significant effects of opposing signs turn up in some subsamples, as will be seen below. Literacy and missing observations are jointly significant: $P(\mathrm{Soc}=0)$ measures the p-value on a test of the null hypothesis that these coefficients are jointly zero, and has a value of 0.02 or less.

Overall a comparison of the 2 columns in Table 4 shows that there is a fingerprint of economic, political and social conditions in the basic station data, and that this fingerprint is slightly diminished but still significant in the gridded data. The similarity of the coefficient estimates between the 2 models is obvious. A test that all socioeconomic influences are jointly zero rejects at well over $99 \%$ for both the station and gridded data sets.
Based on these results, we tentatively conclude that contamination of station data by regional non-climatic signals is significant, and carries over to IPCC gridded data. Some of the variables in this model, such as coal use and Soviet status, have potentially ambiguous meaning. Various econometric tests for parameter stability and model misspecification will be applied in Sections 4 and 5 below. In Section 6 we use the coefficients from Column 2 of Table 4 to factor out the extraneous influences on the vector of gridded trends, on the assumption that the socioeconomic coefficients represent contaminating influences. A possible rival interpretation of the results in Table 4 is that the temperature data are, in fact, measuring real climate trends, but the spatial pattern of change over land can coincidentally be represented either by socioeconomic characteristics or by the physical layout of the atmospheric general circulation. Either way it creates a nontrivial problem for interpreting global warming data. If the former interpretation is true, then climate data is contaminated by extraneous signals that may prove difficult to remove. If the latter interpretation is correct, it implies that socioeconomic signals and 'greenhouse' signals are collinear in conventional temperature data, so standard signal detection methods (e.g. Tett et al. 1999) cannot discriminate among rival hypotheses about the causes of measured global warming.

\subsection{Income-based sample split}

When studying socioeconomic factors, a relevant division of the world is based on income. That economic growth acts differently on the local environment depending on the development context is a common theme in the literature concerning the so-called 'Environmental Kuznets Curve' (see Grossman \& Krueger 1995, Ekins 1997). Extensive empirical evidence shows that the consequences of economic growth on the local environment are worse in low-income countries than in higher income countries, and for some air and water pollutants the relationships have opposite signs. That is, growth in a low-income setting worsens local environmental conditions, whereas in high-income economies growth correlates with reduced pollution. Among other things, this suggests that the nature of industrial growth and its effects on the local atmosphere is not uniform between developed and underdeveloped economies.

This pattern is borne out here. Table 5 shows results based on a sample split for wealthy countries and poor countries, where the former are defined as those countries with per capita income of at least US\$6000. This puts, for instance, Spain and Italy in the wealthy category, but all the former Soviet countries in the 
Table 5. Parameter estimates for surface trend model on economic subsamples. Dependent variable is temperature trend in ${ }^{\circ} \mathrm{C} /$ decade at surface in either station data set or gridded data set. Definitions and notes as for Table 4

\begin{tabular}{|c|c|c|c|c|c|c|c|c|}
\hline \multirow{3}{*}{$\begin{array}{l}\text { Variable } \\
\text { CONSTANT }\end{array}$} & \multicolumn{4}{|c|}{ Wealthy region } & \multicolumn{4}{|c|}{ Poor region } \\
\hline & \multicolumn{2}{|c|}{ Station data } & \multicolumn{2}{|c|}{ Gridded data } & \multicolumn{2}{|c|}{ Station data } & \multicolumn{2}{|c|}{ Gridded data } \\
\hline & -22.608 & $(0.91)$ & -7.499 & $(1.20)$ & $-11.377^{*}$ & $(1.73)$ & $-10.206^{*}$ & $(1.87)$ \\
\hline PRESS $_{i}$ & 0.021 & $(0.87)$ & 0.007 & $(1.14)$ & $0.011^{*}$ & $(1.76)$ & $0.010^{*}$ & (1.91) \\
\hline$W A T E R_{i}$ & 0.126 & $(1.26)$ & 0.014 & $(0.25)$ & 0.131 & (2.09) & 0.043 & $(1.29)$ \\
\hline$C O S A B L A T_{i}$ & $-0.145^{*}$ & $(1.92)$ & -0.078 & $(2.22)$ & 0.037 & $(0.80)$ & $-0.039^{*}$ & $(1.68)$ \\
\hline$P O P_{i}$ & -0.002 & $(0.40)$ & 0.000 & $(0.13)$ & 0.005 & $(1.16)$ & -0.005 & (2.39) \\
\hline$S C A L E 79_{i}$ & 0.001 & $(0.13)$ & -0.002 & $(0.51)$ & 0.011 & $(0.59)$ & 0.010 & $(0.77)$ \\
\hline$C O A L 80_{i}$ & -0.769 & (3.17) & -0.713 & $(5.97)$ & -0.397 & $(1.31)$ & -0.037 & $(0.30)$ \\
\hline COALGROW & -0.031 & $(2.63)$ & -0.013 & $(2.90)$ & 0.001 & $(0.15)$ & 0.002 & $(0.73)$ \\
\hline INC79 & 0.069 & $(2.70)$ & 0.066 & $(7.26)$ & -0.003 & $(0.09)$ & 0.006 & $(0.40)$ \\
\hline GDPGROW $_{i}$ & $0.107^{*}$ & $(1.73)$ & 0.098 & (3.86) & 0.064 & $(3.30)$ & $0.021^{*}$ & $(1.78)$ \\
\hline$S O V I E T_{i}$ & & & & & 0.694 & $(5.43)$ & 0.291 & $(4.20)$ \\
\hline$S U R F M I S S_{i}$ & -0.005 & $(1.05)$ & -0.034 & $(6.87)$ & 0.001 & $(0.59)$ & -0.000 & $(0.04)$ \\
\hline LIT79 & 0.008 & $(1.15)$ & 0.001 & $(0.19)$ & $-0.003^{*}$ & $(1.74)$ & -0.002 & (1.99) \\
\hline $\mathrm{R}^{2}$ & 0.30 & & 0.50 & & 0.34 & & 0.30 & \\
\hline Adj-R $R^{2}$ & 0.19 & & 0.42 & & 0.27 & & 0.23 & \\
\hline $\mathrm{R}^{2}-\mathrm{Geog}$ & 0.02 & & -0.01 & & 0.05 & & 0.12 & \\
\hline$P($ Econ $=0)$ & 0.00 & & 0.00 & & 0.00 & & 0.03 & \\
\hline$P($ Sov $=0)$ & & & & & 0.00 & & 0.00 & \\
\hline$P(\mathrm{Soc}=0)$ & -0.29 & & 0.00 & & 0.20 & & 0.14 & \\
\hline df & 68 & & 67 & & 125 & & 113 & \\
\hline
\end{tabular}

low-income category. The first thing to note is that the general pattern observed in Table 4 holds up: coal consumption, economic growth and Soviet status exhibit discernible influences in the relevant subsamples. The effects of economic activity and coal consumption are significant in the wealthy countries, while social indicators like literacy are not. The fact that coal use has no significant effect in the poor region subsample indicates, among other things, that that which is being measured is not a global effect but a local or regional effect, consistent with the work of Charlson et al. (1992). It is also seasonal in nature, as will be demonstrated below. The rate of missing data appears to exert a cooling bias in the gridded data from wealthy regions: an additional 10 missing months in the record is associated with a trend decline of $0.34^{\circ} \mathrm{C} /$ decade.

In poor countries, variations in energy use and income are not significant, but overall economic growth is. Interestingly the station data show no significant effect from population, but in the post-adjustment gridded data a negative and significant effect emerges, amounting to $-0.01^{\circ} \mathrm{C} /$ decade (relative to the station data) for every 100000 persons.

The Soviet effect is extremely large $\left(+0.69^{\circ} \mathrm{C} /\right.$ decade) and significant in the low-income station data. It is smaller $(+0.29)$ but still significant $(t=4.32)$ in the gridded data. Again, we emphasize that the region covered by the Soviet variable coincides with maximum barometric pressure and therefore may conflate 2 quite different effects. In poor countries the effects of literacy and missing records are about the same magnitudes between the 2 data sources, though only literacy is significant. Twelve of the 13 regions with missing grid cell data are in the low-income countries.

\subsection{Moisture-based and seasonal sample split}

The climatology of a region exhibits sensitivity to the mean water vapour level. As explained in Michaels et al. (2000), we can expect infrared-absorption due to increased $\mathrm{CO}_{2}$ levels to exert a greater local temperature influence in relatively dry airmasses; the expected effect will be stronger the higher is local air pressure, and strongest in the cold season. To check for the relative importance of this pattern, the IPCC gridded data were used to compute cold season and warm season trends, and the regression analysis was run separately on both the global and the dry-region subsamples. The 'warm' season is defined as April to September in the North Hemisphere and October to March in the South Hemisphere; and vice-versa for the cold season. Dry regions were identified as those with negative mean dewpoint.

The results are in Table 6. The dependent variable in all cases is the IPCC gridded data. In dry regions (Columns 2,4), air pressure is positive and significant in the cold season but not the warm season. In the cold, dry subsample, apart from a marginally significant 
Table 6. Parameter estimates for gridded trend model, cold/warm season subsamples; global and dry regions. Dependent variable is seasonal temperature trend in gridded data set. Cold season: October-March in the North Hemisphere; April-September in the South Hemisphere; reverse for warm season. Variable definitions and notes as for Table 4

\begin{tabular}{|c|c|c|c|c|c|c|c|c|}
\hline \multirow{3}{*}{$\begin{array}{l}\text { Variable } \\
\text { CONSTANT }\end{array}$} & \multicolumn{4}{|c|}{ Cold season } & \multicolumn{4}{|c|}{ Warm season } \\
\hline & \multicolumn{2}{|c|}{ Global sample } & \multicolumn{2}{|c|}{ Dry regions } & \multicolumn{2}{|c|}{ Global sample } & \multicolumn{2}{|c|}{ Dry regions } \\
\hline & $-8.373^{*}$ & $(1.68)$ & $-18.239^{*}$ & $(1.96)$ & -11.240 & (2.31) & 2.727 & $(0.32)$ \\
\hline PRESS $_{i}$ & $0.009^{*}$ & $(1.73)$ & 0.018 & (2.17) & 0.011 & (2.36) & -0.001 & $(0.18)$ \\
\hline$W A T E R_{i}$ & 0.031 & $(0.85)$ & 0.069 & $(0.70)$ & 0.001 & $(0.03)$ & -0.008 & $(0.12)$ \\
\hline$C O S A B L A T_{i}$ & -0.022 & $(0.86)$ & 0.023 & $(0.42)$ & -0.064 & $(2.93)$ & -0.050 & $(1.28)$ \\
\hline$P_{i}$ & -0.001 & $(0.35)$ & $-0.025^{*}$ & (1.80) & -0.002 & $(1.44)$ & -0.008 & $(0.67)$ \\
\hline$S C A L E 79_{i}$ & -0.001 & $(0.40)$ & 0.011 & (1.16) & -0.000 & $(0.03)$ & 0.005 & $(0.66)$ \\
\hline COAL $80_{i}$ & -0.002 & $(0.02)$ & -0.090 & $(0.47)$ & -0.436 & (3.81) & -0.564 & (3.10) \\
\hline COALGROW & -0.000 & $(0.00)$ & -0.013 & $(0.82)$ & -0.004 & $(1.43)$ & 0.014 & $(1.27)$ \\
\hline INC79 & 0.033 & (4.47) & 0.045 & (1.33) & 0.026 & $(4.43)$ & 0.018 & $(0.69)$ \\
\hline GDPGROW & 0.033 & (2.18) & -0.012 & $(0.23)$ & 0.039 & (3.76) & 0.045 & $(1.23)$ \\
\hline SOVIET $_{i}$ & 0.223 & (3.32) & -0.035 & $(0.11)$ & 0.302 & (4.45) & 0.289 & $(1.25)$ \\
\hline SURFMISS $_{i}$ & -0.003 & $(0.23)$ & -0.045 & $(1.25)$ & -0.022 & $(2.22)$ & 0.053 & (2.01) \\
\hline LIT79 & -0.003 & (3.01) & -0.003 & $(0.22)$ & -0.003 & $(2.85)$ & -0.011 & $(0.89)$ \\
\hline $\mathrm{R}^{2}$ & 0.23 & & 0.34 & & 0.29 & & 0.31 & \\
\hline Adj-R $R^{2}$ & 0.18 & & 0.18 & & 0.25 & & 0.13 & \\
\hline $\mathrm{R}^{2}-\mathrm{Geog}$ & 0.03 & & 0.00 & & 0.06 & & 0.02 & \\
\hline$P($ Econ $=0)$ & 0.00 & & 0.13 & & 0.00 & & 0.02 & \\
\hline$P(\operatorname{Sov}=0)$ & 0.00 & & 0.92 & & 0.00 & & 0.22 & \\
\hline$P(\mathrm{Soc}=0)$ & 0.01 & & 0.46 & & 0.00 & & $0.09^{*}$ & \\
\hline df & 193 & & 47 & & 196 & & 46 & \\
\hline
\end{tabular}

effect from population, no other effect is significant in the cold season/dry region subsample. It is noteworthy that the Soviet coefficient goes negative (though is insignificant): this implies caution is warranted in interpreting the large positive Soviet coefficients in other specifications, since they may reflect some confounding influence from meteorological phenomena affecting that part of the world. Table 6, Columns 1 and 3 show that in the global sample the seasonal pressure effect is significant or marginally significant and of similar magnitude to that observed in the global annual sample (about $+0.01^{\circ} \mathrm{C} /$ decade $\mathrm{mb}^{-1}$ ). The income, growth, literacy and Soviet effects are significant in both the cold and warm seasons in the global sample, but not in the dry-region subsamples. Coal use is only a significant factor in the warm season trends, indicating that what is being picked up here is a temporary local effect.

If we take the coefficient on $P R E S S_{i}$ to represent a 'greenhouse' signal, the implication of Tables $4 \& 6$ is that the effect is small but observable in the global sample, but is concentrated in dry, high pressure cold season airmasses. These largely form in Siberia and northwestern North America (see Fig. 1a in Michaels et al. 2000). Elsewhere the effect is not consistently observable, and the temperature data are dominated by non-climatic factors. The absence of a dominant greenhouse effect in lower tropospheric temperature anomalies was recently demonstrated in Kärner (2002) using time-series methods.

\section{MODEL SPECIFICATION TESTS}

We now subject the results from Table 4 to a series of tests for model misspecification. The results are all shown in Table 7 . The first column is a repeat of Table 4, Column 2 for comparison. The specification tests all refer to the results using the gridded IPCC data.

\subsection{Outliers and influential observations}

A good test for parameter stability is to see whether the results are sensitive to the removal of so-called 'influential' observations, which is sometimes called 'leverage.' These are detected as follows (see Kmenta 1986). The equation for the OLS predicted values can be written as $\mathbf{H y}=\hat{\mathbf{y}}$, where $\mathbf{y}$ is a vector of dependent variable observations and $\hat{\mathbf{y}}$ is the OLS prediction. $\mathbf{H}$ is called the 'hat' matrix and has dimension $n \times n$ where $n$ is the sample size, and the $i$ th element along its diagonal is denoted $h_{i i}$. The diagonal elements are all between 0 and 1 and sum to $K$, the number of independent variables, so the average value of $h_{i i}$ is $K / n$. If the model is re-estimated with observation $j$ deleted, the change in the parameter estimates is positively related to $h_{j j}$. As a general rule if $h_{j j}>2 K / n$ (i.e. greater than twice the average value) then observation $j$ is considered influential.

Eleven observations were identified as influential and deleted. The parameters were re-estimated on the 
Table 7. Specification tests for surface trend model on annual gridded data. Details as for Table 4; also see Section 4 . df in Column 4 refers to 2 separate estimation stages. S-T DIFF: difference between surface and tropospheric trends

\begin{tabular}{|c|c|c|c|c|c|c|c|c|c|c|}
\hline \multirow{2}{*}{$\begin{array}{l}\text { Variable } \\
\text { CONSTANT }\end{array}$} & \multicolumn{2}{|c|}{$\begin{array}{c}\text { Global } \\
\text { sample } \\
\text { Gridded data }\end{array}$} & \multicolumn{2}{|c|}{$\begin{array}{c}\text { Outliers } \\
\text { removed } \\
\text { Gridded data }\end{array}$} & \multicolumn{2}{|c|}{$\begin{array}{c}\text { S-T DIFF } \\
\text { Global sample }\end{array}$} & \multicolumn{2}{|c|}{$\begin{array}{l}\text { Orthogonal } \\
\text { model } \\
\text { Gridded data }\end{array}$} & \multicolumn{2}{|c|}{$\begin{array}{c}\mathrm{NA}+\mathrm{SA} \\
\text { removed } \\
\text { Gridded data }\end{array}$} \\
\hline & -9.124 & (2.13) & $-6.952^{*}$ & $(1.77)$ & -2.382 & $(0.76)$ & -11.250 & (2.98) & -2.305 & $(0.53)$ \\
\hline PRESS $_{i}$ & 0.009 & (2.18) & $0.007^{*}$ & (1.82) & 0.003 & $(0.84)$ & 0.011 & (3.05) & 0.002 & $(0.58)$ \\
\hline$W_{A T E R_{i}}$ & 0.012 & (0.39) & 0.020 & (0.65) & -0.003 & $(0.14)$ & 0.023 & $(0.71)$ & 0.029 & $(0.81)$ \\
\hline$C O S A B L A T_{i}$ & -0.048 & (2.46) & -0.044 & (2.34) & -0.049 & (3.03) & -0.052 & (2.44) & -0.054 & (2.44) \\
\hline$P O P_{i}$ & -0.002 & (1.26) & -0.004 & (1.09) & -0.002 & (1.35) & -0.002 & $(1.24)$ & -0.004 & (1.35) \\
\hline$S C A L E 79_{i}$ & -0.000 & $(0.02)$ & -0.000 & $(0.10)$ & 0.000 & $(0.14)$ & -0.000 & $(0.05)$ & 0.005 & (1.42) \\
\hline COAL $80_{i}$ & -0.323 & (3.40) & -0.296 & (2.83) & -0.134 & (2.01) & -0.330 & (3.64) & -0.011 & $(0.08)$ \\
\hline COALGROW & -0.002 & $(0.85)$ & -0.001 & $(0.41)$ & $0.003^{*}$ & $(1.75)$ & -0.002 & $(0.78)$ & $-0.006^{*}$ & (1.83) \\
\hline INC79 & 0.030 & (5.22) & 0.034 & (5.20) & $0.008^{*}$ & $(1.74)$ & 0.030 & (5.26) & 0.017 & (2.31) \\
\hline GDPGROW & 0.039 & (3.68) & 0.034 & (3.00) & 0.002 & $(0.17)$ & 0.039 & (3.72) & 0.028 & (2.19) \\
\hline SOVIET $_{i}$ & 0.288 & (4.73) & 0.319 & (5.33) & $0.099^{*}$ & (1.91) & 0.286 & (4.87) & $0.135^{*}$ & (1.87) \\
\hline SURFMISS $_{i}$ & -0.001 & $(0.16)$ & -0.001 & $(0.12)$ & 0.014 & (2.50) & -0.001 & $(0.10)$ & -0.007 & (1.14) \\
\hline LIT79 & -0.002 & (2.81) & -0.003 & (3.09) & -0.003 & (3.74) & -0.003 & (3.12) & -0.000 & $(0.36)$ \\
\hline $\mathrm{R}^{2}$ & 0.29 & & 0.33 & & 0.22 & & 0.24 & & 0.33 & \\
\hline Adj-R $R^{2}$ & 0.25 & & 0.27 & & 0.17 & & 0.20 & & 0.26 & \\
\hline $\mathrm{R}^{2}-$ Geog & 0.06 & & 0.05 & & 0.02 & & 0.06 & & 0.10 & \\
\hline$P($ Econ $=0)$ & 0.00 & & 0.00 & & 0.01 & & 0.00 & & 0.02 & \\
\hline$P($ Sov $=0)$ & 0.00 & & 0.00 & & $0.06^{*}$ & & 0.00 & & $0.06^{*}$ & \\
\hline$P(\mathrm{Soc}=0)$ & 0.02 & & 0.01 & & 0.00 & & 0.01 & & 0.51 & \\
\hline $\mathrm{df}$ & 192 & & 181 & & 192 & & 201/195 & & 129 & \\
\hline \multirow{2}{*}{\multicolumn{5}{|c|}{$\begin{array}{l}\text { Correlation between predicted and observed } \\
\mathrm{R}^{2} \text { between predicted and observed }\end{array}$}} & & & & & 0.31 & \\
\hline & & & & & & & & & 0.09 & \\
\hline
\end{tabular}

remaining data and the results are in Column 2 of Table 7. The fit improves slightly in the full model. Neither signs nor approximate magnitudes of any parameters are affected. With respect to inferences concerning the economic and social factors, all the results are preserved, indicating that they are not spurious effects of a few anomalous station records.

\subsection{Surface-tropospheric differences}

The apparent discrepancy in global warming rates as measured by the surface network and the satellite MSU system has been oft-noted and subject to vigorous scientific discussion (Michaels et al. 2000, National Research Council 2000, Santer et al. 2001). Here we test to see if the spatial pattern of surface trends may reflect geographic variations in lower tropospheric temperature trends that are inappropriately being identified as socioeconomic factors by the regression model.

The vector of tropospheric trends in $2.5^{\circ}$ grid boxes with centers corresponding to the IPCC grid cells for the period 1979:1 to 2000:12 were obtained from the MSU record of the Global Hydrology and Climate Center (GHCC ${ }^{5}$, see Christy et al. 1997, Hurrell et al. 2000). The data product version 5.1, dated March 2003,

${ }^{5} \mathrm{GHCC}_{\text {; http://www.ghcc.msfc.nasa.gov/temperature/ }}$ was used for these calculations. A vector of tropospheric trend coefficients $M T R E N D_{i}$ for the 218 sample locations was generated using the same method as for the surface data, and the vector of surface-troposphere trend differences $S T D I F F_{i}=G T R E N D_{i}-M T R E N D_{i}$ was used as the dependent variable in Eq. (2). These differences were studied in Jones et al. (1997) and are related to those examined recently in Kalnay \& Cai (2003). The results are shown in Table 7, Column 3.

The results are quite similar to the original results, despite removing the spatial variation in the tropospheric trend data, though there are some noteworthy differences. Some of the economic effects are attenuated, especially coal use and Soviet origin of the gridded data. By contrast a strong positive effect associated with rates of missing surface data emerges and the literacy effect is preserved. This test pertains to the rival interpretation discussed in Section 3.1. It is less likely that the patterns picked up in the surface trend data can be attributed to atmospheric temperature change bearing a spurious socioeconomic fingerprint since a comparable fingerprint is found in the differences between the surface and tropospheric trends measured using completely difference instrumentation. A regression of the differences just on the geographic variables has an adjusted $\mathrm{R}^{2}$ (Adj- $\mathrm{R}^{2}$ ) of only 0.02 , indicating that most of the explanatory power is with the nonclimatic variables. 


\subsection{A stepwise model}

The previous section showed that a pressure-related warming signal is observable especially on the spatial pattern of cold-season trends. In this section we repeat the experiment using a stepwise procedure that 'stacks the odds' in favour of identifying climatic effects at the expense of the socioeconomic effects. The procedure involves first regressing $G T R E N D_{i}$ on the geographic variables only: $P R E S S_{i}, W A T E R_{i}$ and COSABLAT $T_{i}$, then regressing the residuals from this regression (which we denote $R S_{i}$ ) on the remaining variables in Eq. (2). If there is little change in the coefficient estimates between the original simultaneous model and the stepwise procedure, this indicates that the variables omitted in the first step are orthogonal to the included variables, and hence they contribute unique explanatory power to the model.

The results are in Column 4 of Table 7 . The coefficients on CONSTANT through COSABLAT are from the first stage regression, then the remaining coefficients are based on a regression of $R S_{i}$ on the socioeconomic variables. The $\mathrm{R}^{2}$ and $\mathrm{Adj}-\mathrm{R}^{2}$ refer to the second-stage model, while $\mathrm{R}^{2}$-Geog is the adjusted $\mathrm{R}^{2}$ from the first stage. Comparing with Column 1 it is clear that the coefficients exhibit no important changes of magnitude, nor are significance levels lost. We can conclude that the socioeconomic effects contribute unique explanatory power in the model.

Returning to the question of whether the socioeconomic variables might be collinear with enhanced greenhouse forcing, which would imply the results in Table 4 are spurious, we find it rather implausible that the socioeconomic variables could so neatly overlap the spatial effects of the general circulation as regards amplification or attenuation of 'greenhouse forcing'. However, if this were the case, it would constitute a serious problem for signal detection studies that interpret temperature data and attempt to attribute causation in climate change. But note the results from the orthogonal model in Table 7: after removing the spatial patterns due to latitude, pressure and coastal proximity, the exact same socioeconomic parameters are returned. This provides counter-evidence to the possibility that they are merely collinear to the spatial layout of greenhouse forcing, and strongly suggests they are actual patterns in the temperature data.

\section{OUT-OF-SAMPLE PROPERTIES}

A final specification test is the ability of this model to support out-of-sample conclusions. The results are in Column 5 of Table 6, which shows the parameters from a re-estimation of the model using GTREND $D_{i}$ as the dependent variable and with the 67 North American and South American locations removed from the sample. The parameters from the subsample regression were then used to predict the withheld North and South American values. The correlation between the predicted and (withheld) observed values is 0.31. A regression of the observed on the predicted values has an $\mathrm{R}^{2}$ of 0.09 and a significant regression $F$-statistic $(\mathrm{p}=0.00)$.

\section{GENERATING ‘CLEAN’ CLIMATE TRENDS}

The parameters in Table 4 can be used to estimate what the trends might look like if the social and economic influences were removed from the data. To do this requires making some judgments about what it means to 'remove' the extraneous signals. A variety of experiments will be done, which will show that the nonclimatic influences likely add up to a net warming bias.

A first approach will be to define the conditional expectation of the gridded trend $E\left(G T R E N D_{i}\right)$ based on the global sample parameter estimates with the effects of economic variables set to zero and literacy set to $99 \%$ everywhere, yielding the model:

$$
\begin{aligned}
E\left(\operatorname{GTREND}_{i}\right)= & \alpha+\hat{\gamma}_{1} \mathrm{PRESS}_{i}+\hat{\gamma}_{2} \text { WATER }_{i}+ \\
& \hat{\gamma}_{3} \operatorname{COSABLAT}_{i}+\hat{\theta}_{4} \times 99
\end{aligned}
$$

where the `denotes the generalized least squares parameter estimate from Eq. (2).

Table 8 shows the effects of implementing these changes sequentially. Setting the economic covariates to zero drops the sample average warming rate from $0.27^{\circ} \mathrm{C} /$ decade to $0.11^{\circ} \mathrm{C} /$ decade. Removing the social effects by setting literacy to $99 \%$ for all countries and setting the number of missing observations to zero drops the sample average trend to $0.06^{\circ} \mathrm{C} /$ decade, close to the long-run (100 yr) trend in numerous analyses of global mean temperature series (Galbraith \& Green 1992, Woodward Gray 1993, Zheng \& Basher

Table 8. Values of sample average temperature trends in gridded data after successively removing extraneous socioeconomic biases

\begin{tabular}{|lcc|}
\hline Adjustment & $\begin{array}{c}\text { Adjusted sample } \\
\text { Average trend } \\
\left({ }^{\circ} \mathrm{C} / \text { decade }\right)\end{array}$ & $\begin{array}{c}\text { Adjusted } \\
\text { sample } \\
\mathrm{SD}\end{array}$ \\
\hline Original sample average & 0.270 & 0.237 \\
Remove economic effects & 0.110 & 0.125 \\
Remove social effects & 0.063 & 0.136 \\
Remove soviet effect & 0.011 & 0.053 \\
Set income to sample average & 0.201 & 0.053 \\
\hline
\end{tabular}


1999, Fomby \& Vogelsang 2000), but substantially below the surface trend since 1979, which is $0.18^{\circ} \mathrm{C} /$ decade. It is noteworthy that the remaining warming is the same as given in a recent compilation of the MSU-satellite data (Christy et al. 2003).

An additional removal of the Soviet effect drops the warming trend to $0.01^{\circ} \mathrm{C} /$ decade, but this risks removing some cold-season warming that is properly attributable to greenhouse changes. Further disentanglement of the Soviet, socioeconomic and cold-weather greenhouse effects is certainly an area in need of further investigation.

Setting income $\left(I N C 79_{i}\right)$ to zero effectively assumes it is uniformly contaminating with a warm bias. An alternative interpretation is that at low income levels the lack of public resources impairs quality control in ways additional to that represented by the educational variable, which would imply that low income causes a cooling bias. If there are offsetting effects that reverse into a warming bias depending on the income level, that might be picked up using a quadratic specification (i.e. by adding the square of $I N C 79_{i}$ to Eq. 2). This was tried, but the estimated coefficient was very small and insignificant, and none of the other results were affected. However, in case there are resource-constraint effects if income falls too low, the above calculations were re-done setting each country's per capita income to the global sample mean (US\$6440). As shown in Table 8 , this raises the globally averaged trend to about $0.2^{\circ} \mathrm{C} /$ decade, about one-third below the sample average.

\section{DISCUSSION AND CONCLUSIONS}

It is well-established that the basic land-based weather station temperature data have been affected by local factors related to economic growth and land-use changes, but claims have been made that these effects have been identified and removed in gridded records. This study provides evidence that the contamination has not been removed, and that it adds up to a net warming bias at the globally averaged level. Consequently surface temperature data, including the IPCC gridded cell series, should not be interpreted as if they only measure 'climate.' They reflect the influence of many things, including a complex blend of local economic and social factors. Some of these exert an indirect influence on local temperatures but have nothing to do with the global climate, while others have nothing to do with temperature at all but instead affect data quality control. This study provides evidence that after controlling for these, the observed rate of temperature change is noticeably lower in a global sample, and depending on how economic influences are removed, could be as low as that observed in the satellite record. Hence, attempts to identify the magnitude of a global 'greenhouse' climate signal on surface data without properly removing the extraneous biases (e.g. Tett et al. 1999) risks exaggerating the perceived influence of atmospheric $\mathrm{CO}_{2}$ levels.

If the post-1979 temperature trends were lower than is typically thought, the question arises whether a similar analysis conducted over the 1961 to 1979 interval would indicate larger reductions in temperature than previously thought, and if so, how or whether such changes could be explained based on current understanding of climate forcing mechanisms. It is not necessarily the case that socioeconomic factors would add up to a net warming bias as they appear to do after 1979, because the international economic situation was not the same in the 2 decades before 1979 as those after. For instance, the 1970 s was marked by persistently weak real income growth in western economies, which gave way to rapid growth in the mid-1980s. Also, the Soviet Union did not experience a calamity comparable to 1990-1991. However this is certainly an interesting direction for further research.

As with any application of statistics the results embed particular modeling assumptions. Eq. (2) fits the spatial pattern of surface temperature trends to the spatial pattern of dry air pressure, some geographic factors and socioeconomic factors. Establishing such a fit is not proof of causality; to some extent one must accept the premises of the equation. This includes the idea that fitting a linear trend through monthly averages of temperature observations over the post-1979 interval provides meaningful climatic data. Since temperature is an intensive thermodynamic variable, averages taken over time or space do not have a unique physical relationship with the underlying temperature field (Essex \& McKitrick 2002), thus linear time trends at best support a heuristic interpretation. Another premise of Eq. (2) is that the explanatory variables can be interpreted as they stand, rather than being treated as proxies for some other variables with quite different interpretations. Some of the specification tests in Table 7 addressed this potential concern. Overall, the results of this study support the hypothesis that published temperature data are contaminated with nonclimatic influences that add up to a net warming bias, and that efforts should be made to properly quantify these effects.

Acknowledgements. B. O'Rae, N. Clayton and C. Knappenberger provided helpful research assistance. For comments and suggestions we thank, without implicating, M. Khandekar, 4 anonymous referees and participants in the American Meteorological Society 14th Conference on Applied Climatology, Seattle. Funding from the University of Guelph University Research Assistant Bursary program and from the Social Sciences and Humanities Research Council of Canada is gratefully acknowledged. 


\section{LITERATURE CITED}

Balling RC, Hughes WS (1996) Urban influences on South African temperature trends. Int J Climatol 16:935-940

Böhm R (1998) Urban bias in temperature time series - a case study for the city of Vienna, Austria. Clim Chang 38:113-128

Charlson RJ , Schwartz SE, Hales JM, Cess RD, Coakley JA, Hansen JE, Hoffman DJ (1992) Climate forcing by anthropogenic aerosols. Science 255:423-430

Christy JR, Spencer RW, Braswell WD (1997) How accurate are satellite 'thermometers'? Nature 389(25):342

Christy JR, Spencer RW, Norris WB, Braswell WD (2003) Error estimates of Version 45.0 of MSU-AMSU bulk atmospheric temperatures. J Atm Ocean Tech 20:613-629

Ekins P (1997) The Kuznets curve for the environment and economic growth: examining the evidence. Environ Planning A 29:805-830

Essex C, McKitrick R (2002) Taken by storm: the trouble science, policy and politics of global warming. Key Porter Books, Toronto

Fomby T, Vogelsang T (2000) The application of size-robust trend statistics to global warming temperature series. Working Paper, September 2000. Cornell University, Ithaca, NY

Friedrich K, Mölders N, Tetzlaff G (2000). On the influence of surface heterogeneity on the Bowen ratio: a theoretical case study. Theor Appl Climatol 65:181-196

Fujibe F (1995). Temperature rising trends at Japanese cities during the last hundred years and their relationships with population, population increasing rates and daily temperature ranges. Pap Met Geophys 46(2):35-55

Galbraith JW, Green C (1992) Inference about trends in global temperature data. Clim Change 22:209-221

Gallo KP, Owen TW, Easterling DR, Jamason PF (1999). Temperature trends of the US Historical Climatology Network based on satellite-designated land use/land cover. J Clim 12:1344-1348

Grossman GM, Krueger AB (1995) Economic growth and the environment. Q J Econ 109:353-377

Hansen J, Ruedy R, Sato M, Imhoff M, Lawrence W, Easterling D, Peterson T, Karl T (2001) A closer look at United States and global surface temperature change. J Geophys Res 106:23947-23963

Heston A, Summers R (1991) The Penn World Table (Mark 5): an expanded set of international comparisons, 1950-1988. Q J Econ 106:327-368

Hingane LS (1996). Is a signature of socioeconomic impact written on the climate? Clim Change 32:91-102

Hurrell JW, Brown S, Trenberth K, Christy JR (2000) Comparison of tropospheric temperatures from radiosondes and satellites: 1979-98. Bull Am Meteorol Soc 81:2165-2177

Intergovernmental Panel on Climate Change (IPCC) Summary for policy makers. In: Houghton JT, Ding Y, Grigg DJ, van der Linden PJ, Xiaosu D (eds) Climate change 2001: the scientific basis. Contributions of Working Group I to the Third Assessment Report of the Intergovernmental Panel on Climate Change (IPCC). Cambridge University Press, Cambridge, p 1-20

Jacobson M (2001) Strong radiative heating due to the mixing state of black carbon in atmospheric aerosols. Nature 409: 695-697

Jenne RL (1974) Jenne's Northern Hemisphere Climatology, Monthly, 1950-64. National Center for Atmospheric Research Dataset DS205.0. National Center for Atmospheric Research, Boulder, CO
Jones PD, Moberg A (2003) Hemispheric and large-scale surface air temperature variations: an extensive revision and an update to 2001. J Clim 16:206-223

Jones PD, Osborne TJ, Wigley TML, Kelly PM, Santer BD (1997) Comparisons between the microwave sounding unit temperature record and the surface temperature record from 1976 to 1996: Real difference or potential discontinuities? J Geophys Res 102(D30):135-145

Jones PD, Groisman PY, Coughlan M, Plummer N, Wang WC, Karl TR (1990) Assessment of urbanization effects in time series of surface air temperature over land. Nature 347: 169-172

Kalnay E, Cai M (2003) Impacts of urbanization and land use change on climate. Nature 423:528-531

Kärner O (2002) On nonstationarity and antipersistency in global temperature series. J Geophys Res 107(D20):ACL 1-1-1-11

Kmenta J (1986) Elements of econometrics. MacMillan, New York, NY

Linacre E (1992) Climate data and resources: a reference and guide. Routledge, London.

Magee N, Curtis J, Wendler N (1999) The urban heat island effect at Fairbanks, Alaska. Theor Appl Clim 64:39-47

Michaels PJ, Knappenberger PC (2000) Natural signals in the MSU lower tropospheric temperature record. Geophys Res Lett 27:2905-2908

Michaels PJ, Knappenberger PC, Balling RC Jr, Davis RE (2000) Observed warming in cold anticyclones. Clim Res $14: 1-6$

National Research Council (2000) Reconciling observations of global temperature change. National Academy Press, Washington, DC

Peterson TC, Vose RS (1997) An overview of the global historical climatology network temperature database. Bull Am Meteor Soc 78:2837-2849

Pielke RA Sr, Marland G, Betts RA, Chase TN, Eastman JL, Niles JO, Niyogi DDS, Running SW (2002) The influence of land-use change and landscape dynamics on the climate system: relevance to climate-change policy beyond the radiative effect of greenhouse gases. Phil Trans R Soc Lond A 360:1705-1719

Santer BD, Wigley TML, and 8 others (2001) Accounting for the effects of volcanoes and ENSO in comparisons of modeled and observed temperature trends. J Geophys Res 106:28033-28059

Staley DO, Jurica GM (1970) Flux emissivity tables for water vapor, carbon dioxide and ozone. J Appl Meteorol 9: 365-372

Tett, SFB, Stott PA, Allen MR, Ingram WJ, Mitchell JFB (1999) Causes of twentieth century temperature change near the Earth's surface. Nature 399:569-572

Torok SJ, Morris CJ, Skinner C and Plummer N (2001) Urban heat island features of southeast Australian towns. Aust Met Mag 50:1-13

White H (1980) A heteroskedasticity-consistent covariance matrix estimator and a direct test for heteroskedasticity. Econometrica 48:817-838

White K (1993) SHAZAM econometrics computer program users manual. McGraw-Hill, Toronto

Woodward WA, Gray HL (1993) Global warming and the problem of testing for trend in time series data. J Clim 6: 953-962

Zheng X, Basher RE (1999) Structural time series models and trend detection in global and regional temperature series. J Clim 12:2347-2358 